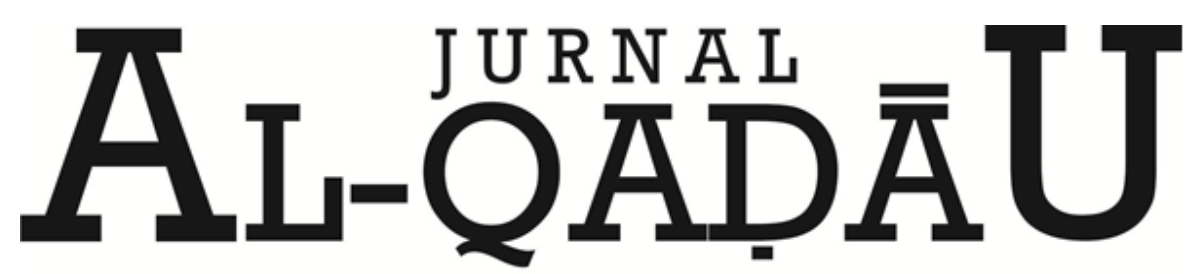

PERADILAN dan HUKUM KELUARGA ISLAM

\title{
Tinjauan Hukum Islam terhadap Istri sebagai Pencari Nafkah Utama dalam Keluarga PNS di Kecamatan Enrekang Kabupaten Enrekang
}

The Overview of Islamic Law towards Wife as a breadwinner in civil servant family in Enrekang

Suharna

Pascasarjana UIN Alauddin Makassar

Email: suharnaismail@gmail.com

\begin{tabular}{|c|c|}
\hline $\begin{array}{l}\text { Info } \\
\text { Artikel }\end{array}$ & Abstract \\
\hline $\begin{array}{l}\text { Diterima } \\
19 \\
\text { Februari } \\
2018\end{array}$ & $\begin{array}{l}\text { Penelitian ini membahas tentang Tinjauan Hukum Islam Terhadap Istri } \\
\text { Sebagai Pencari Nafkah Utama Dalam Keluarga PNS di Kecamatan } \\
\text { Enrekang Kabupaten Enrekang. Jenis penelitian adalah penelitian } \\
\text { kualitatif. Peran seorang istri yang ada di Kecamatan Enrekang pada } \\
\text { dasarnya sebagai ibu rumah tangga. Sebagai istri terhadap suaminya dan } \\
\text { sebagai ibu terhadap anak-anaknya. Istri yang juga ikut mencari nafkah } \\
\text { dalam keluarga. Penyebab istri juga ikut mencari nafkah keluarga di } \\
\text { Kecamatan Enrekang; pertama karena faktor ekonomi, faktor sosial, gaya } \\
\text { hidup. Kondisi keluarga di Kecamatan Enrekang pada umumnya } \\
\text { disebabkan karena faktor ekonomi yang menyebabkan sang istri sangat } \\
\text { berperan aktif dalam mencari nafkah terhadap keluarganya. Hukum Islam } \\
\text { tidak melarang istri mencari nafkah selama tidak keluar dari syariat } \\
\text { Islam, bahkan membolehkan membantu suami mencari nafkah keluarga, } \\
\text { selama tidak melalaikan tanggung jawabnya sebagai ibu rumah tangga } \\
\text { karena kebahagiaan dalam keluarga sangat dibutuhkan peran suami } \\
\text { sebagai kepala keluarga dan istri sebagai kepala rumah tangga. }\end{array}$ \\
\hline
\end{tabular}

Revisi II

05

April

2018

\section{Disetujui}

24

Mei

2018
Kata Kunci: Isteri, Nafkah.

This study discusses the Overview of Islamic Law towards wife as financial support (breadwinner) in civil servant family in Enrekang Regency, Enrekang District. The type of research is qualitative research. The role of a wife in Kecamatan Enrekang is basically a housewife. As a wife serves her husband and as a mother looks after her children. Wives also participate in making a living in the family. The causes of the wife also work to earn money in Enrekang because of economic factors, social factors, and lifestyle. The family condition in Enrekang is affected more by economic factors that cause the wives actively involved in earning a living for his family. Islamic law does not prohibit the wives to make money for their family unless the action is not out of Islamic law, even the law allows them to help their husband, as long as not neglect their responsibilities as housewife because happiness in the family is supported by husband role as head of family and wife as head of household.

Keyword: Wife, breadwinner 
Suharna

\section{A. PENDAHULUAN}

Pernikahan ialah ikatan lahir batin antara seorang laki-laki dengan seorang perempuan sebagai suami istri dengan tujuan membentuk keluarga (rumah tangga) yang bahagia dan kekal berdasarkan Ketuhanan Yang Maha Esa. Oleh karena itu, pengertian pernikahan dalam ajaran agama Islam mempunyai nilai ibadah, sehingga pasal 2 Kompilasi Hukum Islam (KHI) menegaskan bahwa pernikahan adalah akad yang sangat kuat (miśqan galidan) untuk menaati perintah Allah swt. dan melaksanakannya merupakan ibadah. ${ }^{1}$

Pernikahan disebut juga perkawinan yang berasal dari kata kawin yang menurut bahasa artinya membentuk keluarga dengan lawan jenis. ${ }^{2}$ Hubungan antara seorang laki-laki dan perempuan adalah merupakan tuntunan yang telah diciptakan oleh Allah swt. dan untuk menghalalkan hubungan ini maka disyariatkanlah akad nikah. Pergaulan antara laki-laki dan perempuan yang diatur dengan pernikahan ini akan membawa keharmonisan, keberkahan dan kesejahteraan baik bagi laki-laki maupun perempuan, bagi keturunan di antara keduanya bahkan bagi masyarakat yang berada di sekeliling kedua insan tersebut.

Hikmah dari pernikahan itu adalah menyalurkan seks, dalam mendapatkan keturunan yang sah, penyaluran naluri kebapaan dan keibuan, dorongan untuk bekerja keras, menjalin silaturahmi antara dua keluarga, yakni keluarga dari pihak suami maupun dari pihak istri. Selain itu hikmah lain yang tidak kalah penting adalah masalah pengaturan hak dan kewajiban dalam rumah tangga. ${ }^{3}$

Disyariatkannya perkawinan adalah untuk mendapatkan ketenangan hidup, mendapatkan cinta dan kasih sayang, serta pergaulan yang baik dalam rumah tangga. Demikian baru dapat berjalan secara baik bila ditunjang dengan tercukupinya kebutuhan hidup yang pokok bagi kehidupan rumah tangga. Kewajiban nafkah adalah untuk menegakkan tujuan dari perkawinan itu. ${ }^{4}$

Apabila akad nikah telah berlangsung dan sah memenuhi rukun dan syaratnya menurut hukum Islam dan hukum nasional, maka akan menimbulkan akibat hukum yang mengandung aspek keperdataan yakni akan menimbulkan hak dan kewajibannya selaku suami istri dalam rumah tangga jika suami istri memahami dan menjalankan kewajibannya masing-masing. Oleh karena itu, antara hak dan kewajiban merupakan hubungan timbal balik antara suami dan istrinya. Maka dengan demikian rumah tangga akan terwujud sesuai dengan tuntunan agama, yakni sakinah, mawaddah, wa rahmah. ${ }^{5}$

Kehidupan keluarga yang ideal menurut hukum Islam adalah keluarga sakinah sebagaimana yang disebutkan sebelumnya, yakni lingkungan rumah tangga yang tenteram, harmonis dan bahagia serta diliputi oleh suasana keagamaan, dengan kriteria utama berdasarkan pernikahan sah menurut syariat Islam, terjalin keikhlasan dan rasa cinta serta kasih sayang yang selalu dipelihara antara suami istri, terpenuhinya kebutuhan hidup yang memadai dengan cara halal, masing-masing memenuhi hak dan

\footnotetext{
${ }^{1}$ Zainuddin Ali, Hukum Perdata Islam di Indonesia (Jakarta: Sinar Grafika, 2006), h. 7.

${ }^{2}$ Dep Dikbud, Kamus Besar Bahasa Indonesia (Cet. III: Jakarta; Balai Pustaka, 1994), h. 456.

${ }^{3}$ Abdurrahman Ghozali, Fiqh Munakahat (Cet. IV: Jakarta; Kencana, 2010), h. 72.

${ }^{4}$ Amir Syarifuddin, Hukum Perkawinan Islam di Indonesia: Antara Fiqh Munakahat dan UndangUndang Perkawinan (Jakarta: Kencana Prenadamedia Group, 2006), h. 167.

${ }^{5}$ Abdurahman Ghozali, Fiqh Munakahat, h. 73.
} 
kewajiban kepada pasangannya, memiliki keturunan yang shalih, adanya kesetiaan dan kasih sayang yang tulus antara ayah, ibu dan anak, terciptanya sistem pembagian kerja yang adil antara suami dan istri dengan melihat kebutuhan serta kenyataan yang dihadapi. ${ }^{6}$

Hal ini diatur di dalam Pasal 30 Undang-Undang No. 1 Tahun 1974 tentang Perkawinan, yakni:

"Suami Istri memikul kewajiban yang luhur untuk menegakkan rumah tangga yang menjadi sendi dasar dari susunan masyarakat"?

Salah satu kewajiban suami terhadap istri adalah mencari nafkah, sesuai dengan Pasal 80 ayat 4 huruf a Kompilasi Hukum Islam. Namun seiring dengan berubahnya cara pandang masyarakat terhadap peran dan posisi kaum perempuan ditengah-tengah masyarakat, maka kini sudah banyak kaum perempuan sudah berkarir/mencari nafkah baik di kantor pemerintah maupun swasta bahkan ada yang berkarir di kemiliteran dan kepolisian, sebagaimana kaum laki-laki. Kehidupan modern tidak memberikan peluang untuk membatasi gerak kaum perempuan. ${ }^{8}$

Kewajiban memberikan nafkah oleh suami kepada istrinya yang berlaku dalam fikih didasarkan kepada prinsip pemisahan harta antara suami dan istri. Prinsip ini mengikuti alur pikir bahwa suami itu adalah pencari rezeki, rezeki yang telah diperolehnya itu menjadi haknya secara penuh dan untuk selanjutnya suami berkedudukan sebagai pemberi nafkah. Sebaliknya istri bukan pencari rezeki dan untuk memenuhi keperluannya ia berkedudukan sebagai penerima nafkah. Oleh karena itu, kewajiban nafkah tidak relevan dalam komunitas yang mengikuti prinsip penggabungan harta dalam rumah tangga. ${ }^{9}$

Akan tetapi dilihat dari realitas yang ada pada saat ini banyak para suami yang mengabaikan kewajiban khususnya dalam hal memenuhi nafkah keluarganya. Oleh sebab itu jika dilihat realitas yang ada pada saat ini para istri yang ikut berperan serta dalam memenuhi nafkah keluarga. Hal ini tentunya sangat tidak relevan dengan yang terdapat dalam undang-undang perkawinan yang ada pada saat ini, yang mana nafkah tersebut merupakan kewajiban seorang suami kepada keluarganya. Hal inilah yang banyak terjadi pada masyarakat Kecamatan Enrekang, yang mana para istri yang berperan aktif dalam hal memberi nafkah dalam keluarga.

Seorang istri bukan berarti tidak mempunyai kewajiban terhadap keluarganya. Namun seorang istripun memiliki kewajiban, tugas dan perannya sebagai istri maupun ibu. Adapun tugas istri secara umum ialah: mengandung, melahirkan, menyusui dan merawat anak-anaknya. Sebuah tugas yang cukup berat dan penting untuk memikul beban ini. Allah swt. membekali perempuan dengan perasaan lemah lembut dan kasih sayang. Dua faktor inilah yang membuat mereka merespon dengan cepat keinginan dan kebutuhan putra putrinya. Dengan demikian, dinilai adil jika kemudian suami kebagian untuk menjaga, mengayomi, serta membimbing istri dan anak-anaknya. Ini pula bagian

${ }^{6}$ M. Quraish Shihab, Membumikan al-Qur'an, (Cet. XVIII; Bandung: Mizan, 1998), h.255. Lihat juga Muhammad al-Sabbaq, Keluarga Bahagia dalam Islam (Solo: Pustaka Marniq, 1994), h. 152.

${ }^{7}$ Republik Indonesia Undang-Undang. No. 1 Tahun 1974 Pasal 30.

${ }^{8}$ Huzaema T. Yanggo. Figh Perempuan Kontenporer. (Jakarta: Ghali Indonesia, 2010), h.62.

${ }^{9}$ Amir Syarifuddin, Hukum Perkawinan Islam di Indonesia: Antara Fiqh Munakahat dan UndangUndang Perkawinan, h. 166. 
Suharna

dari hak istri dari suami, yakni merasa terlindungi. Namun tidak semua yang kita rencanakan dapat berjalan sesuai dengan yang kita inginkan termasuk dalam hal memenuhi nafkah.

Hukum membayar nafkah kepada istri, baik itu dalam bentuk materi maupun yang nonmateri adalah wajib. Kewajiban itu bukan disebabkan oleh karena sang istri membutuhkannya bagi kehidupan rumah tangga, akan tetapi kewajiban itulah yang kemudian timbul dengan sendirinya atas dasar pernikahan dan juga pemberian nafkah itu wajib tanpa melihat keadaan istri yang memang mampu dalam mencari nafkah. Namun berdasarkan data yang peneliti dapatkan di Kecamatan Enrekang sebagai lokasi penelitan, tidak relevan dengan undang-undang perkawinan dan juga Kompilasi Hukum Islam karena di Kecamatan Enrekang itu banyak para istri yang sangat berperan dalam memenuhi nafkah keluarganya.

\section{B. METODE PENELITIAN}

Jenis penelitian adalah penelitian kualitatif dengan pendekatan yang digunakan adalah pendekatan sosiologis, normatif dan pendekatan filosofis. Metode pengumpulan data yang digunakan adalah observasi, wawancara dan dokumentasi. Teknik pengolahan dan analisis data dilakukan melalui tiga tahapan yaitu Reduksi Data, Penyajian dan Pengambilan kesimpulan.

\section{PEMBAHASAN}

\section{Peran Istri dalam Keluarga di Kecamatan Enrekang}

Peran seorang istri sangat penting dalam sebuah keluarga, sehingga sebagai ibu rumah tangga dan seorang istri mempunyai tugas dan kewajiban tersendiri dan terkadang tugas-tugas tidak bisa dialihkan atau digantikan kepada orang lain demi keutuhan dan kebahagiaan keluarga itu sendiri. Oleh karena itu, seorang perempuan harus benar-benar mampu melaksanakan kewajibannya dengan ikhlas dan penuh tanggung jawab.

Berdasarkan hasil penelitian terhadap keluarga PNS di Kecamatan Enrekang dapat dilihat bahwa peran istri sangat penting dalam kehidupan rumah tangga, karena dengan profesinya tersebutlah mereka dapat memenuhi kebutuhan keluarga, bahkan dengan penghasilan sang istri tersebut mereka bisa membangun rumah yang lebih layak untuk tempat tinggal mereka.

Seperti yang diungkapkan oleh ibu Syamsidar:

"Jadi rumah sayaji perbaiki, pokoknya segala-galanya dan biasanya itu tetangga bilang kenapaki bodoh-bodoh perbaiki rumahta na banyakki bersaudara, bilangka bukan perbaiki rumahnya orang tua tapi milikku sama saudara-saudaraku, biasa juga na bilang orang kenapa tidak diperbaiki rumahnya na robohmi, saya ji yang bisa perbaiki karena sayaji yang PNS, sayaji yang kerja, jadi ituji saya jawabanku sama itu tetangga-tetangga kalau na bilangika setengah mati maki itu perbaiki rumahnya orang tuata na banyak ki saudara, ku bilang bukan ku perbaiki untuk jadi milikku sendiri, tapi karena saya yang tinggal."10

\footnotetext{
${ }^{10}$ Syamsidar, Ibu Rumah Tangga di Kecamatan Enrekang, Wawancara, Enrekang, 19 Januari 2018.
} 
Peran seorang istri sangat penting dalam sebuah keluarga, sehingga sebagai ibu rumah tangga dan seorang istri mempunyai tugas dan kewajiban tersendiri dan terkadang tugas-tugas tidak bisa dialihkan atau digantikan kepada orang lain demi keutuhan dan kebahagiaan keluarga itu sendiri. Oleh karena itu, seorang perempuan harus benar-benar mampu melaksanakan kewajibannya dengan ikhlas dan penuh tanggung jawab. Fakta yang terjadi di Kecamatan Enrekang menunjukkan bahwa perempuan sebagai seorang istri dan ibu rumah tangga mengalami perubahan. Sebelumnya meraka hanya berada di rumah untuk mengurusi urusan keluarganya saja. Namun seiring berkembangnya zaman, situasi dan kondisi saat inipun banyak yang berbeda. Apalagi dengan naiknya harga kebutuhan yang semakin lama semakin mahal, menyebabkan mereka memutuskan untuk bekerja di luar rumah seperti sebagai Pegawai Negeri Sipil (PNS), karena mereka berpikiran bahwa menjadi seorang PNS itu dapat bisa memperoleh gaji yang banyak dan dapat memenuhi kebutuhan hidup keluarga.

Suami menjadi kepala keluarga yang memimpin, membimbing dan melindungi keluarga dan gangguan apapun, baik itu lahir maupun batin, serta mencari nafkah dan juga keperluan lainnya untuk sang istri dan juga anak-anaknya. Mendidik serta dapat menjadi suri tauladan bagi anak dan juga istrinya merupakan kewajiban seorang kepala keluarga. Menurut ibu Kismawati terkait dengan peran istri dalam mencari nafkah:

"Suami saya tidak bekerja tidak ada masalah, kita harus sabar walaupun garis tangan suami tidak ada kerjanya, yang penting kita harus saling harga menghargai, kita saling berusaha semaksimal mungkin supaya kita juga seperti orang lain yang baik dan dapat berguna bagi nusa dan bangsa.

Setelah melihat penjelasan dari ibu rumah tangga yang juga sebagai seorang istri, dapat dikatakan bahwa mereka mencari nafkah ada yang memang dasarnya adalah hanya untuk membantu meringankan beban sang suami namun ada juga yang betulbetul menjadi tulang punggung keluarga. Jika memang mencari nafkah itu adalah kewajiban suami, akan tetapi hal tersebut tidak menutup kemungkinan jika seorang istripun juga turut mencari nafkah keluarga seperti yang terdapat di Kecamatan Enrekang Kabupaten Enrekang.

\section{Faktor yang Melatarbelakangi Istri dalam Mencari Nafkah}

Di dalam keluarga kemiskinan adalah situasi atau kondisi dimana seseorang atau yang mencari nafkah tidak mampu untuk memenuhi kebutuhan dasar, baik itu kebutuhan pangan maupun non pangan. Penanggulangan kemiskinan dan ketimpangan distribusi pendapatan merupakan masalah pembangunan suatu negara. Salaj satu tujuan dari pembangunan nasional adalah mewujudkan masyarakat yang sejahtera. Pendapatan merupakan salah satu cara dari indikator untuk mewujudkan atau meningkatkan kesejahteraan masyarakat. Indikator kemiskinan ada pada keluarga pra sejarah dan keluarga sejahtera yang menggambaran kemampuan masyarakat untuk memenuhi kebutuhan pokok dan tempat tinggal. Perekonomian sebuah keluarga sangat dipengaruhi oleh pendapatan keluarga yang bersumber dari pendapatan suami yang bertanggung jawab mencari nafkah dan juga sebagai kepala keluarga. Namun pada suatu kondisi kemiskinan pada saat ini maka istri juga akan ikut berkontribusi bagi pendapatan keluarga. 
Suharna

Kegiatan mencari nafkah adalah kewajiban dan tanggung jawab suami sebagai kepala keluarga, akan tetapi dari hasil pengamatan para istri juga ikut membantu suami dalam mencari nafkah untuk keluarga, hal ini disebebkan karena adanya beberapa faktor, yaitu faktor pendidikan, faktor jumlah tanggungan dan faktor ekonomi yang sangat mempengaruhi para istri yang ikut membantu suami dalam mencari nafkah. Kegiatan istri yang mencari nafkah selain bekerja di rumah ada juga yang bekerja di luar rumah biasanya didasari oleh faktor pendidikan atau karena keahlian yang dimiliki oleh istri.

Sebagaimana yang diungkapkan oleh ibu Ida terkait dengan faktor yang melatarbelakangi sang istri dalam mencari nafkah:

"Istri yang mencari nafkah untuk keluarganya itu disebabkan oleh beberapa faktor, seperti dikeluarga saya itu karena suami saya yang bekerja sebagai tenaga honorer dan tidak mempunyai pekerjaan sampingan, sementara biaya pendidikan sekarang sudah mahal, jika hanya mengaharapkan penghasilan suami itu belum bisa memenuhi kebutuhan keluarga kami, jadi saya sebagai istri juga harus bekerja untuk membantu suami". ${ }^{11}$

Sementara itu, ada juga pendapat dari ibu Hasna terkait dengan faktor yang melatarbelakangi istri dalam mencari nafkah:

"Yang menjadi motivasi saya untuk bekerja adalah anak-anak saya, suami saya meninggal dunia beberapa tahun yang lalu dan saya harus tetap bekerja demi kehidupan keluarga". ${ }^{12}$

Terjunnya istri dalam dunia kerja, banyak membawa pengaruh terhadap segala aspek kehidupan, baik kehidupan pribadi dan keluarga maupun kehidupan masyarakat sekitarnya. Hal demikian dapat menimbulkan dampak positif dan negatif. Dampak positif dengan adanya istri bekerja, antara lainsebagai berikut: ${ }^{13}$

1. Dengan bekerja, istri dapat membantu meringankan beban keluarga yang tadinya hanya dipikul oleh suami yang mungkin kurang memenuhi kebutuhan, tetapi dengan adanya istri ikut berkiprah dalam mencari nafkah, maka krisis ekonomi dapat ditanggulangi.

2. Dengan bekerja, istri dapat memberikan pengertian dan penjelasan kepada keluarganya, utamanya kepada putra-putrinya tentang kegiatan-kegiatan yang diikutinyasehingga jika ia sukses dan berhasil dalam kerjanya, putra-putrinya akan gembira dan bangga, bahkan menjadikan ibunya sebagai panutan dan suri tauladan bagi masa depannya. Hal ini sesuai dengan pengakuan dan pernyataan dari salah seorang anak remaja dari ibu yang bekerja ketika penulis mewawancarainya, bahkan menurutnya banyak hal positif yang mereka temui bila ibunya bekerja, bahkan mereka gembira dan bangga jika ibunya sukses dalam kerjanya.

3. Dalam memajukan serta mensejahterakan masyarakat dan bangsa diperlukan partisipasi serta keikutsertaan kaum perempuan karena dengan segala potensinya, perempuan mampu, dalam hal ini, bahkan ada di antara pekerjaan yang tidak bisa

\footnotetext{
${ }^{11}$ Ida, Ibu Rumah Tangga di Kecamatan Enrekang, Wawancara, Enrekang, 20 Januari 2018.

${ }^{12}$ Hasna, Ibu Rumah Tangga di Kecamat an Enrekang, Wawancara, Enrekang, 20 Januari 2018.

${ }^{13}$ Huzaemah Tahido Yanggo, Fikih Perempuan Kontemporer (Jakarta: Penerbit Ghalia Indonesia, 2010) h. 63-64.
} 
dilaksanakan oleh laki-laki, dapat dilaksanakan oleh perempuan, baik karena keahliannya maupun karena bakatnya.

4. Dengan bekerja, istri dalam mendidik anak-anaknya lebih bijaksana, demokratis dan tidak otoriter, sebab dengan pekerjaannya itu, ia bisa dan belajar memiliki pola pikir yang moderat. Jika ada problem dalam rumah tangga yang harus diselesaikan, maka ia segera mencari jalan keluar secara tepat dan benar.

5. Dengan bekerja, perempuan yang menghadapi kemelut dalam rumah tangganya atau sedang mendapat gangguan jiwa, akan terhibur dan jiwanya akan menjadi sehat, sebagaimana disebutkan oleh Zakiyah Daradjat dalam bukunya Islam dan Peran Perempuan yaitu untuk kepentingan kesehatan jiwanya, perempuan itu harus gesit bekerja.

Adapun uangkapan dari ibu Kamaria terkait dengan faktor yang membuat dia harus bekerja:

"Kalau dari keluarga pertama mi itu ekonomi karena sekarang kan masalah ekonomi kalau ada penghasilanta juga kan beda kalau bapak saja yang berpenghasilan". ${ }^{14}$

\section{Pandangan Hukum Islam tentang Istri Mencari Nafkah}

Islam memandang bahwa perkawinan merupakan kebutuhan biologis yang fitrah bagi kenormalan perilaku. Lebih dari itu, Islam menganggap perkawinan sebagai penyempurnaan agama dan lembaga perkawinan merupakan kriteria hidup yang normal. Islam memotivasi bahkan memerintahkan umatnya untuk segera menikah jika telah mampu untuk melakukannya. Dengan melaksanakan perkawinan berarti ia telah mempersiapkan diri untuk menjaga kehormatannya, untuk istiqamah dan untuk beribadah kepada Allah swt. ${ }^{15}$

Dalam hukum Islam tidak dilarang bagi seorang istri yang ingin bekerja untuk mencari nafkah, selama cara yang ditempuh tidak melenceng dari syariat Islam. Bahkan al-Qur'an secara tegas menuntut laki-laki dan perempuan untuk bekerja dengan kebaikan. Allah swt. telah menciptakan laki-laki dan perempuan sama, jika ditinjau dari sisi insaniahnya (kemanusiannya). Artinya laki-laki dan perempuan diciptakan memiliki ciri khas kemanusiaan yang tidak berbeda antara yang satu dengan yang lain. Kedua-duanya dikaruniai potensi hidup yang sama berupa kebutuhan jasmani, naluri dan akal. Allah swt. juga telah membebankan hukum yang sama terhadap laki-laki dan perempian apabila hukumitu ditujukan untuk manusia secara umum. Misalnya, pembebanan terhadap kewajiban shalat, berpuasa, zakat, haji, menuntut ilmu dan juga mengemban dakwah. Semua ini dibebankan kepada laki-laki dan perempuan tanpa ada perbedaan. Sebab semua kewajiban tersebut dibebankan terhadap manusia seluruhnya, semata-mata karena dengan sifat kemanusiaannya yang ada pada dirinya masing-masing tanpa melihat apakah seseorang itu laki-laki maupun perempuan. Akan tetapi jika suatu hukum ditetapkan khusus untuk jenis manusia tertentu (laki-laki saja atau perempuan saja), maka akan terjadi suatu pembebanan hukum yang berbeda antara laki-laki dan perempuan. Misalnya kewajiban dalam hal

\footnotetext{
${ }^{14}$ Kamaria, Ibu Rumah Tangga di Kecamatan Enrekang, Wawancara, Enrekang, 21 Januari 2018.

${ }^{15}$ Rizal Darwis, Nafkah Batin Istri Dalam Hukum Perkawinan (Gorontalo, Sultan Amai Press, 2015), h. 114.
} 
Suharna

mencari nafkah keluarga atau bekerja hanya dibebankan kepada laki-laki, karena hal ini berkaitan dengan fungsinya sebagai kepala keluarga. Islam telah menetapkan bahwa kepala keluarga adalah tugas pokok dan juga tanggung jawab laki-laki.

Dengan demikian, perempuan tidak terbebani tugas atau tidak diwajibkan mencari nafkah, baik untuk dirinya sendiri maupun untuk keluarganya. Perempuan justru berhak mendapatkan nafkah dari sang suami jika perempuan tersebut telah menikah atau dari walinya jika perempuan tersebut belum menikah. Akan tetapi, bukan dengan jalan mewajibkan perempuan bekerja. Dengan seiring berjalannya zaman, ada pertanyaan yang timbul yaitu bolehkah perempuan bekerja ?. Sekalipun perempuan telah dijamin nafkahnya melalui pihak suami ataupun wali jika perempuan itu belum menikah, itu bukan berarti Islam tidak membolehkan perempuan bekerja untuk mendapatkan harta/penghasilan. Islam membolehkan perempuan untuk mencari dan memiliki harta sendiri. Sebagaimana firman Allah swt. yang membolehkan perempuan dalam berusaha mengembangkan hartanya agar semakin bertambah dalam QS AnNahal/16:97

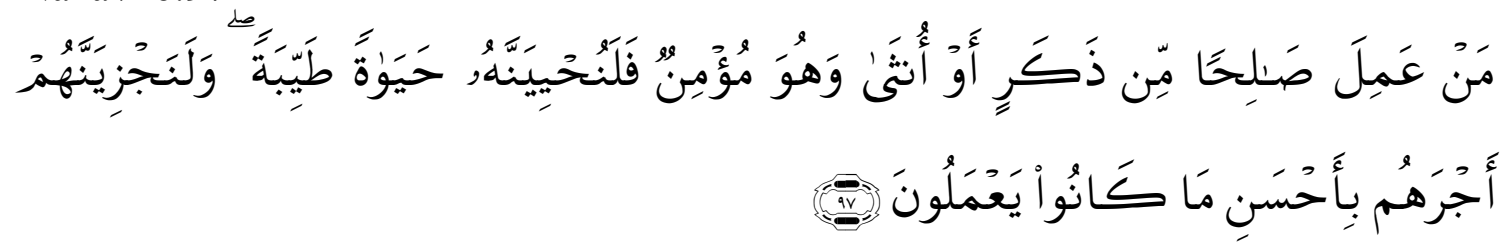

Terjemahnya:

Barangsiapa mengerjakan kebajikan, baik laki-laki maupun perempuan dalam keadaan beriman, maka pasti akan Kami berikan kepadanya kehidupan yang baik dan akan Kami beri balasan dengan pahala yang lebih baik dari apa yang telah mereka kerjakan. ${ }^{16}$

Penjelasan ayat tersebut bahwa laki-laki dan perempuan dalam Islam mendapat pahala yang sama dan amal kebaikan harus disertai iman. Beberapa sahabat perempuan pada masa Rasulullah saw. juga bekerja, termasuk istri dari Rasulullah saw. sendiri yaitu Siti Khadijah yang berprofesi sebagai pengusaha, baik itu untuk kepentingan ekonomi, sosial maupun agama. Dengan demikian, Islam sebenarnya mendukung perempuan ataupun yang sudah menjadi istri itu bekerja dengan tujuan-tujuan yang positif. Meskipun ada ketentuan-ketentuan yang menyatakan bahwa kewajiban mencari nafkah itu ada di pundak laki-laki atau suami, sebagaimana firman Allah swt. yang telah dijelaskan dalam QS al-Nisā/4:34

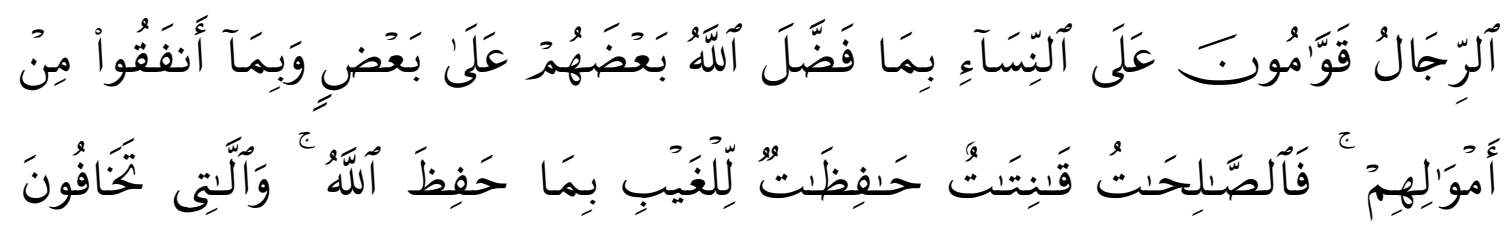

${ }^{16}$ Kementerian Agama RI, al-Qur'an al-Karim dan Terjemahnya (Jakarta: Halim, 2013), h. 278. 


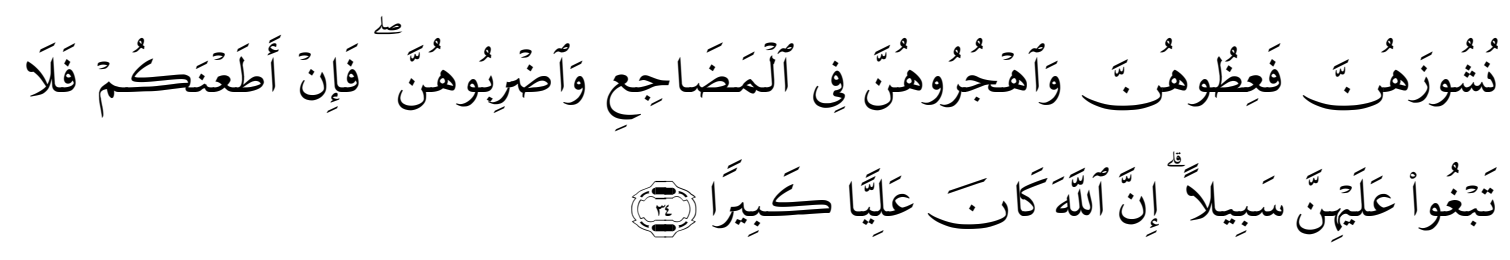

Terjemahnya:

Laki-laki (suami) itu pelindung bagi perempuan (istri), karena Allah telah melebihkan sebagian mereka (laki-laki) atas sebagian yang lain (perempuan), dan karena mereka (laki-laki) telah memberikan nafkah dari hartanya. Maka perempuan-perempuan yang saleh, adalah mereka yang taat (kepada Allah) dan menjaga diri ketika (suaminya) tidak ada, karena Allah telah menjaga (mereka). Perempuan-perempuan yang kamu khawatirkan akan nusyûz, hendaklah kamu beri nasihat kepada mereka, tinggalkanlah mereka di tempat tidur (pisah ranjang), dan (kalau perlu) pukullah mereka. Tetapi jika mereka menaatimu, maka janganlah kamu mencari-cari alasan untuk menyusahkannya. Sungguh, Allah Mahatinggi, Mahabesar. ${ }^{17}$

Dalam fikih, sebenarnya tidak ada teks yang secara eksplisit melarang isti untuk bekerja, namun jangan sampai diabaikan tugas pokok istri yaitu sebagai ibu dan pengatur rumah tangga serta terhadap pendidikan dan pembentukan akhlak bagi anakanaknya, juga menjaga kehormatannya. Hal tersebut dihukumi wajib karena ada konsekuensi pertanggung jawaban kepada Allah swt. Istri tidak dibebani atau tidak dibebankan untuk bekerja dalam hal ini mencari nafkah baik untuk dirinya sendiri maupun untuk keluarganya, justru berhak mendapatkan nafkah dari suaminya. Dengan kata lain seandainya dia bekerja maka dihukumi mubah selama tetap masih bisa menjalankan tugasnya sebagai pengasuh terhadap anak-anaknya dan dapat menjaga diri dan kehormatannya. Akan tetapi, jika sudah tercukupi nafkahnya dari suami maka seharusnya perempuan atau istri harus mendahulukan yang wajib dan mengabaikan yang mubah, karena yang wajib itu lebih berat konsekuansinya atau pertanggung jawabannya kepada Allah swt.

\section{KESIMPULAN}

1. Peran seorang istri di Kecamatan Enrekang pada dasarnya sebagai ibu rumah tangga. Sebagai istri terhadap suaminya dan sebagai ibu terhadap anak-anaknya. Istri yang juga ikut mencari nafkah dalam keluarga, itu ada yang betul-betul mengambil tanggung jawab suami akan tetapi ada juga yang posisinya hanyalah membantu meringankan beban suami karena keluarga bukan hanya tanggung jawab suami, melainkan tanggung jawab bersama.

2. Faktor penyebab sehingga istri juga ikut mencari nafkah keluarga di Kecamatan Enrekang; pertama faktor ekonomi, suami tidak bekerja sehingga istri kemudian menjadi tulang punggung keluarga, suami telah meninggal dunia jadi istri yang menjadi satu-satunya yang mencari nafkah, penghasilan dari suami belum cukup untuk biaya kehidupan keluarganya sehingga melibatkan istri dalam mencari nafkah. Kedua karena faktor sosial, gaya hidup yang semakin modern dan biaya

\footnotetext{
${ }^{17}$ Kementerian Agama RI, al-Qur'an al-Karim dan Terjemahnya, h. 84.
} 
Suharna

pendidikan yang juga semakin mahal menyebabkan istri sangat berperan dalam membantu suami untuk memenuhi kebutuhan keluarga. Akan tetapi, Kondisi keluarga di Kecamatan Enrekang pada umumnya disebabkan karena faktor ekonomi yang menyebabkan sang istri sangat berperan aktif dalam mencari nafkah terhadap keluarganya, terkhusus bagi para ibu rumah tangga yang telah ditinggal mati oleh sang suami.

3. Kehidupan berkeluarga di Kecamatan Enrekang, hukum Islam tidak melarang jika istri mencari nafkah, selama tidak keluar dari syariat Islam. Hukum Islam malah membolehkan jika istri dapat membantu suami mencari nafkah keluarga, akan tetapi istri tidak boleh melalaikan tanggung jawabnya sebagai ibu rumah tangga.

\section{Implikasi}

Kehidupan berkeluarga, istri sangat menginginkan suatu kebahagiaan dalam rumah tangganya baik itu dalam keadaan suka maupun duka. Penelitian ini, sangat diharapkan agar mempunyai dampak positif bagi kehidupan keluarga sehingga bisa menjadi lebih baik khususnya dalam hal pemenuhan nafkah keluarga agar senantiasa terbina keluarga yang Sakinah Mawaddah wa Rahmah. Hukum Islam memandang kehidupan keluarga, dapat disimpulkan bahwa kebahagiaan dalam keluarga itu sangat dibutuhkan peran suami sebagai kepala keluarga dan istri sebagai kepala rumah tangga.

\section{DAFTAR PUSTAKA}

Abdulrahman. Kompilasi Hukum Islam, Jakarta: CV Akademika pressindo. 2007.

Ali, Zainuddin, Hukum Perdata Islam di Indonesia, Jakarta: Sinar Grafika, 2012.

Badan Pengembangan dan Pembinaan Bahasa, Kamus Besar Bahasa Indonesia, Cet.4; Jakarta: Balai Pustaka Jakarata, 2008.

Daradjat, Zakiah. Islam dan Peranan Wanita, Jakarta: Bulan Bintang, 1983.

Jauhar, Husain. Ahmad Al-Mursi, Maqashid Syariah, Jakarta: Amzah, 2013.

Kementrian Agama RI. al-Qur'an dan Terjemahannya, Jakarta: Halim, 2013.

Kuzairi, Achmad. Nikah sebagai Perikatan . Jakarta; PT. Raja Grafindo Persada. 1995.

Nasution, Harun dan Bahtiar Effendy. Hak Asasi Manusia Dalam Islam. Asia Foundation, 1987.

Pudjosumedi dan Ahmad Tahrizurrahiim., Islam dan Peranan Wanita. Solo: CV Aneka, 1996.

Shihab, M. Quraish., Membumikan al-Qur'an: Fungsi dan Peran Wahyu dalam Kehidupan Masyarakat. Bandung: Mizan, 1995.

Syarifuddin, Amir, Hukum perkawinan Islam di Indonesia, Jakarta: prenada media. 2007.

Tahindo yanggo, Huzaema. Fiqh Perempuan Kontenporer. Jakarta: ghali Indonesia . 2010. 